\title{
Modelling the relationship between climate, winegrape price and winegrape quality in Australia
}

\author{
L. B. Webb ${ }^{1,2, *}$, P. H. Whetton ${ }^{1}$, E. W. R. Barlow ${ }^{2}$ \\ ${ }^{1}$ CSIRO Marine and Atmospheric Research, PMB 1, Aspendale, Victoria 3195, Australia \\ ${ }^{2}$ School of Agriculture and Food Systems, University of Melbourne, Parkville, Victoria 3010, Australia
}

\begin{abstract}
An essential pre-requisite to exploration of the potential impacts of climate change on wine quality is to establish a robust relationship between winegrape quality and climate. Here, Australian wine industry regional scale climate and winegrape quality information were evaluated. A model that describes the climate sensitivity of quality measures for premium winegrape varieties grown in Australia is presented. The relationship between winegrape quality and climate varies for the different varieties examined: with some varieties, a linear reduction in quality in response to a warmer climate is exhibited, while a quadratic relationship of quality change with increasing temperature is exhibited by some other varieties. For varieties displaying a more linear relationship, the relative sensitivities to changes in growing season temperature can be calculated. For example, Cabernet Franc and Pinot Noir are the varieties displaying the greatest sensitivity to temperature changes in Australian winegrowing regions, while Semillon, Chardonnay and Shiraz are less responsive. For varieties displaying a quadratic relationship of quality to temperature, the optimum growing temperature can be calculated. The optimum mean January temperature $\left({ }^{\circ} \mathrm{C}\right)$ for growing of Cabernet Sauvignon in Australia is $18.5^{\circ} \mathrm{C}$; for Shiraz, $19.1^{\circ} \mathrm{C}$; Verdelho, $20.7^{\circ} \mathrm{C}$; and Ruby Cabernet, $21.5^{\circ} \mathrm{C}$. Our study reveals the sensitivity of winegrape quality to climate, and should help to quantitatively inform the Australian wine industry of its potential exposure to projected climatic changes.
\end{abstract}

KEY WORDS: Winegrape price $\cdot$ Winegrape quality $\cdot$ Climate $\cdot$ Temperature $\cdot$ Winegrape variety

\section{INTRODUCTION}

According to the Intergovernmental Panel on Climate Change (IPCC 2007) increasing emissions of carbon dioxide and other greenhouse gases are altering the composition of the atmosphere. It is very likely that most of the warming since the mid-20th century is due to increases in greenhouse gases from human activities (IPCC 2007). Eleven of the last $12 \mathrm{yr}$ (1995 to 2006) rank among the 12 warmest years in the instrumental record of global surface temperature (since 1850). Regardless of the actions that we take today, some degree of warming is inevitable (IPCC 2007).

There are 2 reasons for which the study of the wine industry as it is affected by climate and climate change is particularly relevant. (1) Winegrapes Vitis vinifera are traditionally grown in unique 'terroirs', of which climate is a critical component, to produce a range of wines with varying and individual characteristics (Seguin 1986). Terroir is a complex concept, but for the purposes of the present study it can be defined as a combination of soil, climate and cultural practice involved in wine production. (2) Winegrape vines have an expected productive life of $>50 \mathrm{yr}$. Within that timeframe the climate is projected to change significantly, and, consequently, the potential impact on vineyards being currently planted poses an immediate and significant risk to wine companies. These companies have large investments in highquality vineyards and the associated winery infrastructure. A model illustrating just how much the quality of winegrapes will be affected by the future warmer climate can assist the industry in assessing the climate risk of exposure and inform the industry as to the level of urgency required to adapt to a specific impact. 
Winegrape quality has been linked to temperature in some past studies. Jackson \& Lombard (1993) surveyed the world's viticultural areas and found, providing that a climate is sufficiently warm enough to ripen a specific winegrape variety, quality will be inversely related to warmth and length of summer. Winegrape quality is reduced in hot regions (White et al. 2006), and absence of extreme heat has been linked to higher quality wine production (Gladstones 1992). In hot regions winegrapes ripen at a faster rate, allowing less leeway for picking the optimum harvest time, in addition, the crushing of the grapes is more likely to take place at higher temperatures, increasing the likelihood of oxidation faults (Coombe 1987).

The level of temperature at ripening is found to influence colour production, flavour and aroma profiles, tannin type and levels, and sugar to acid ratios (Coombe \& Iland 2004). All of these factors, for each wine grape variety, combine to produce a particular wine style, often unique to a region. 'Quality' is a measure, not only of these biophysical factors, but also any synergies between these. A key limitation in research on the living fruit of the grapevine is that of what to measure that correlates with quality. Development of a robust climate-winegrape quality model has not been undertaken before this evaluation, possibly due to the difficulty in quantifying quality, and also perhaps because no need was recognised prior to the publication of increasingly compelling - and now convincing - evidence that the climate is changing (IPCC 2007).

Aligning the winegrape variety to the climate is fundamental to producing quality wine (Jackson \& Lombard 1993). Exploiting phenological differences between various winegrape varieties allows selection of the variety that will ripen at the optimum time of the harvest cycle for a particular site. Winegrapes are grown in a large number of growing regions, representing a range of climates in Australia, from the very coolest and marginal areas in the southern part of the continent, with climates similar to the Champagne and Chablis regions of France, to hot inland areas similar to sites in southern Italy and Greece (Johnson 1989). A correspondingly large range of grape varieties is also produced across these different growing regions. While some varieties can produce good quality wine from a range of climate types, others are not as robust (Kerridge \& Antcliff 1996). If the climate warms, how will the different grape varieties be affected? Testing the response to climate, as it varies for different winegrape varieties, will be one of the primary aims of the present study.

The approach used here was to undertake continental scale GIS (geographical information system)-based spatial assessment of Australian viticultural parameters, which represent winegrape quality, and then relate these variables to regional climate parameters with the objective being the generation of a quantitative relationship between climate and winegrape quality. Inter-regional climate and vineyard production comparisons are used, rather than intra-regional or inter-annual '1-site' climate variability analysis, so that broad-scale differences are captured.

\section{DATA AND METHODS}

\subsection{Climate parameters affecting winegrape quality}

This assessment was undertaken using data from the diverse climatic range of vineyard regions found in Australia, from very hot to very cool. There are currently 60 winegrowing regions in Australia (AWBC 2006) (Fig. 1). A number of climate indices, which have been identified in previous studies as being linked to winegrape quality, were selected and tested in this analysis (Table 1). Climate descriptors focusing on the period from veraison (commencement of winegrape ripening) to harvest are used in this assessment, as this part of the growing season has the most influence on winegrape quality (Coombe \& Iland 2004).

Digital climate maps (1961 to 1990) (BoM 2007), gridded at a $25 \times 25 \mathrm{~km}$ resolution, were accessed. The climate data were extracted for Australian wine regions using ArcGIS 9.0 software intersect techniques (ESRI 2007), and an area-weighted average for each climate variable was calculated. In extracting the regional climate data, it was necessary to assume that the average regional climate represented the parts of the region in which the winegrapes are grown.

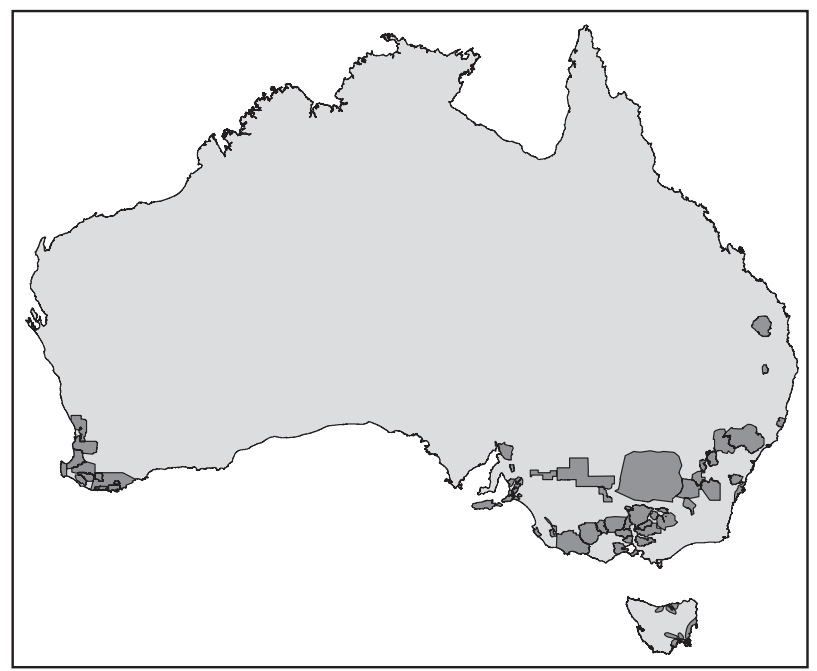

Fig. 1. Australian winegrowing regions (geographical indications) (http://www.wineaustralia.com/australia/) 
Table 1. Selected climate variables linked to winegrape quality in the Southern Hemisphere. DJF: December-February

\begin{tabular}{|c|c|}
\hline Climate variable & Source \\
\hline Mean January temperature $(\mathrm{MJT})\left({ }^{\circ} \mathrm{C}\right)$ & Smart \& Dry (1980) \\
\hline $\begin{array}{l}\text { Growing degree days }>10^{\circ} \mathrm{C}\left(\mathrm{GDD}_{10}\right) \\
\left({ }^{\circ} \mathrm{C}\right) \text {. Summation of the average monthly } \\
\text { temperatures }\left(>10^{\circ} \mathrm{C}\right) \text { from October to } \\
\text { April in the Southern Hemisphere }\end{array}$ & Amerine \& Winkler (1944) \\
\hline $\begin{array}{l}\text { Latitude temperature index. Defined as } \\
\text { mean temperature of the warmest } \\
\text { month, multiplied by ( } 60 \text { - Site Latitude) }\end{array}$ & Jackson \& Cherry (1988) \\
\hline $\begin{array}{l}\text { Harvest maximum temperature } \\
\text { (mean, December-March) }\left({ }^{\circ} \mathrm{C}\right)\end{array}$ & $\begin{array}{l}\text { Haselgrove et al. (2000), } \\
\text { Marais et al. (2001), Spayd et } \\
\text { al. (2002), White et al. (2006) }\end{array}$ \\
\hline $\begin{array}{l}\text { Annual rainfall (mm) } \\
\text { Summer rainfall (mean, December- } \\
\text { March) }(\mathrm{mm}) \\
\text { Potential evaporation (DJF) (mm) }\end{array}$ & $\begin{array}{l}\text { Koundouras et al. (2006), } \\
\text { Magarey et al. (1994), } \\
\text { Rodo \& Comin (2000) }\end{array}$ \\
\hline $\begin{array}{l}\text { Continentality (January mean tempera- } \\
\text { ture - July mean temperature) }\left({ }^{\circ} \mathrm{C}\right)\end{array}$ & $\begin{array}{l}\text { Gladstones (1992), } \\
\text { Smart \& Dry (1980) }\end{array}$ \\
\hline $\begin{array}{l}\text { Diurnal range (January max. mean } \\
\text { temperature - January min. mean } \\
\text { temperature) }\left({ }^{\circ} \mathrm{C}\right) \\
\text { Minimum January temperature }\left({ }^{\circ} \mathrm{C}\right)\end{array}$ & $\begin{array}{l}\text { Gladstones (1992), } \\
\text { Kliewer \& Torres (1972), } \\
\text { Tonietto \& Carbonneau (2004) }\end{array}$ \\
\hline
\end{tabular}

(Kliewer \& Torres 1972, Francis et al. 1999, Haselgrove et al. 2000, Spayd et al. 2002). It has been found that anthocyanin levels of the skin of berries are reduced when the berries are exposed to high temperatures (Haselgrove et al. 2000, Spayd et al. 2002). While neither the G-G assay, nor the colour analysis, directly and exclusively measures the critical flavour components in winegrapes, it is likely that there is a sufficiently close correlation between the concentrations of glycosylated secondary metabolites in winegrape berries and the level of those important individual compounds that result in wine flavour (Francis et al. 1999).

Winegrape colour and G-G data were used in this analysis and came from a nationwide survey conducted in 1997 by the Australian Wine Research Institute (Francis et al. 1998). Data were from winegrapes of ripeness between total soluble solids (TSS) of 20 and 24 degrees Brix $\left({ }^{\circ} \mathrm{Bx}\right)$. TSS indicates the level of sugar ripeness (Coombe \& Iland 2004). Colour was measured as the concentration of total anthocyanins

Because the relationship between climate and winegrape quality was determined using climate data and quality data from the years 1999 to 2003, and we know the climate is not static (IPCC 2007), the climate data were adjusted with greenhouse warming levels appropriate to the year 2000 using the CSIRO OzClim software (Page \& Jones 2001). The adjustment in this case was based on the SRES A1B greenhouse gas and aerosol emission scenario (Nakićenović \& Swart 2000), assuming mid-range climate sensitivity and regional patterns of climate change from the CSIRO Mk3 climate model.

\subsection{Selecting a winegrape quality indicator}

No one standard measure of winegrape or wine quality exists (Coombe \& Iland 2004). The definition of quality is elusive, and, for this reason, quality indicators had to be assessed for their suitability to be used in the present study. Many possible winegrape quality indicators were considered with a view to selecting an indicator that links with climate measures.

Winegrape colour and glycosyl-glucose (G-G) (a winegrape flavour and aroma precursor compound) are measures of winegrape quality that respond directly to the environment in which they are grown in the grape $\left(\mathrm{mg} \mathrm{g}^{-1}\right)$. G-G was extracted as described by Francis et al. (1999), and was measured by concentration in the grape $\left(\mathrm{mg} \mathrm{g}^{-1}\right)$. Note that the colour data are only available from 24 regions, and data collected for the G-G measure were limited to 14 regions.

An economic quality indicator, the weighted average weighbridge price paid per tonne of winegrapes (AWBC 2006), provides another possible indicator of the quality of winegrapes. For the most part, wine quality, governed by winegrape quality, is rewarded by the price point that is able to be achieved by the finished product. One of the major considerations in wine pricing is the cost of production, and the major cost involved in wine production is the cost of winegrapes (Edwards \& Spawton 1990). A winery would not pay high prices for winegrapes if it could not achieve the corresponding high price for the resulting wine. Different varieties, regions, vineyards, vintages, wineries and wines command significantly different prices for their winegrapes in Australia (Allen 2003). This price differential has been linked to wine and winegrape quality in some studies (Golan \& Shalit 1993, Oczkowski 1994, Unwin 1999, Haeger \& Storchmann 2006).

The economic indicator of winegrape quality, price paid for winegrapes (\$A t $\mathrm{t}^{-1}$ ) (AWBC 2006) was available from 35 winegrape-growing regions. The 
Australian Wine and Brandy Corporation (AWBC) conducts an annual nationwide survey in which winegrape prices paid at the weighbridge are collected, and these data, weighted so that each separately priced batch is proportionally represented, are recorded. The average price is determined for each variety in a given region and published. These price data represent a minimum of $95 \%$ of the national winegrape crush annually (except in 2002 the Australian Regional Winegrape Crush Survey [ARWCS] response fell marginally below the $95 \%$ benchmark; AWBC 2003).

The price data used in this analysis represent the average regional and varietal prices from 1999 to 2003 inclusive (AWBC 2006). As well as using the average price paid for winegrapes over the 5 yr to reduce any possible anomalies in the pricing data, comparison of the individual year's price data to detect any supply and demand pricing trends was carried out. The analysis revealed no significant differences in the prices paid in the given years, though a downward trend was noted, particularly for red winegrape varieties, grown in the warmer regions. These trends were also noted by Oczkowski (2006) who assessed the winegrape price disequilibrium for the years from 2000 to 2003.

Another assigned indicator that has been considered as a potential quality indicator for the wine industry was wine ratings. Some recent studies have linked climate with vintage ratings in the context of climate change impact to wine quality (Nemani et al. 2001, Jones et al. 2005). For this assessment wine ratings data published by Hooke \& Kyte-Powell (2003) were evaluated, whereby the ratings data for all unblended Cabernet Sauvignon wines were analysed. It was found that there was a large variation in the number of samples representing each region. For example, Coonawarra was strongly represented with 14 wines described, while 10 out of the 23 regions that had a Cabernet Sauvignon wine product assessed had only 1 wine described. For this reason it was difficult to assess any relationship trends between wine ratings and climate. Reliability of wine show or review data has been questioned by some other reviewers in Australia (Coombe \& Iland 2004), and, as our intention was to assess the impact on winegrapes, not wine, alternative methods for assessing quality were sought.

Winegrape colour, levels of G-G and winegrape price were selected as quality measures for this evaluation. G-G and colour data were available for the varieties Shiraz and Cabernet Sauvignon. Pricing data were available for all varieties purchased in Australia over the period of the analysis. This analysis will be limited to selected premium winegrape varieties only. Premium varieties used were defined in an economic analysis of the Australian Wine Industry (Osmond \& Anderson 1998) and are the red grape varieties Caber- net Sauvignon, Shiraz, Merlot, Pinot Noir, Cabernet Franc, Malbec, Grenache and Ruby Cabernet. The white grape varieties evaluated are Chardonnay, Sauvignon Blanc, Riesling, Semillon, Traminer and Verdelho.

Initially, principal component analysis (PCA) of the relationship between the climate variables was carried out to identify links between the climate drivers. By implementing this procedure highly correlated variables can be removed from the data file. Previous studies comparing wine quality with climate have used this statistical approach (Cichelli et al. 2000). A correlative assessment of the relationship between the quality indicators G-G, colour and price and the selected climate variables was then undertaken.

The multivariate analysis and other relationship testing described above were followed by regression analysis of the selected data sets. This was carried out using the statistical package SPSS 11.0 (SPSS 2001). Both linear relationships and second-order relationships describing the relationship between climate and winegrape quality were determined as they varied for each winegrape variety. The sensitivity of each variety to climate is described. Confidence intervals (CIs) are defined to provide an estimate of error in the model.

\section{RESULTS AND DISCUSSION}

\subsection{Selection of quality/climate indicator variables}

PCA was employed to determine whether links between the climatic indices that influence winegrape quality existed. All of the relevant climate variables, averaged over each winegrowing region, were analysed to detect interrelationships. Three components describing the variance in the data were detected (Table 2). The first component describes the 'heat' or temperature indices of climate, with mean January temperature $\left(\mathrm{MJT}_{;}{ }^{\circ} \mathrm{C}\right), \mathrm{GDD}_{10}\left({ }^{\circ} \mathrm{C}\right), \operatorname{LTI}\left({ }^{\circ} \mathrm{C}\right)$, harvest maximum temperature $\left({ }^{\circ} \mathrm{C}\right)$ and continentality $\left({ }^{\circ} \mathrm{C}\right)$ all linked in the same component and all showing high loadings. A second climate component is evident with diurnal range and minimum January temperature $\left({ }^{\circ} \mathrm{C}\right)$ being the main contributing climate variables, while summer rainfall and continentality are the variables dominating the third component.

These 3 climate components, or the climate variable with the highest loading from these components, are used in further analysis of the relationship between winegrape quality and climate (Table 3 ).

Relationships between the winegrape quality estimators (discussed here before consideration of the climate estimators) are found to be significant. The G-G and colour levels (for Shiraz and Cabernet Sauvignon) 
Table 2. Principal component analysis evaluating regionally averaged climate variables from Australian wine regions (these climate indices may influence winegrape quality). Each number represents the correlation between the climate variable and the component. Three components have been extracted. Bold: highly correlated variables

\begin{tabular}{|lrrr|}
\hline Component & 1 & 2 & 3 \\
\hline \% Variance explained & 59 & 18 & 15 \\
Mean January temperature $(\mathrm{MJT})\left({ }^{\circ} \mathrm{C}\right)$ & $\mathbf{0 . 9 9}$ & 0.13 & -0.03 \\
Growing degree days $>10^{\circ} \mathrm{C}(\mathrm{GDD} 10)\left({ }^{\circ} \mathrm{C}\right)$ & $\mathbf{0 . 9 2}$ & 0.32 & -0.15 \\
Latitude temperature index $(\mathrm{LTI})$ & $\mathbf{0 . 8 6}$ & 0.41 & 0.13 \\
Harvest temperature $\left({ }^{\circ} \mathrm{C}\right)$ & $\mathbf{0 . 9 7}$ & -0.17 & 0.05 \\
Annual rainfall $(\mathrm{mm})$ & -0.56 & 0.50 & 0.21 \\
Summer $(\mathrm{DJF})$ rainfall $(\mathrm{mm})$ & -0.08 & 0.33 & $\mathbf{0 . 9 2}$ \\
Potential evaporation summer $(\mathrm{DJF})(\mathrm{mm})$ & $\mathbf{0 . 9 0}$ & -0.20 & -0.25 \\
Continentality $\left({ }^{\circ} \mathrm{C}\right)$ & $\mathbf{0 . 6 6}$ & -0.31 & $\mathbf{0 . 6 4}$ \\
Diurnal range $\left({ }^{\circ} \mathrm{C}\right)$ & 0.50 & $-\mathbf{0 . 7 7}$ & 0.21 \\
Min. January temperature $\left({ }^{\circ} \mathrm{C}\right)$ & 0.76 & $\mathbf{0 . 6 1}$ & -0.15 \\
\hline
\end{tabular}

tation is one of those factors (Schamel \& Anderson 2003); for instance, grapes grown in a region such as the Barossa Valley or Coonawarra may command a premium price compared with a lesser known region such as Langhorne Creek. Regional branding is now becoming an industry focus to capitalise on this factor (WFA 2007). Other influences such as production costs, product differentiation and wine style branding/fashion will also affect the price paid for grapes (Edwards \& Spawton 1990).

Comparison of the representative variables of the 3 climate components (identified in the PCA analysis; Table 2) with the quality indicators results in a significant inverse relationship between correlate significantly and in a positive way with winegrape price. Comparison of the 2 biophysical quality indicators show that regionally averaged colour data are positively correlated with winegrape price for both Shiraz and Cabernet Sauvignon winegrapes (Table 3). Regionally averaged G-G data are also positively correlated with winegrape price for both Shiraz and Cabernet Sauvignon winegrapes, though this relationship is only statistically significant for the Cabernet Sauvignon winegrapes. Winegrape colour and the level of G-G are positively and significantly correlated across regions. While G-G and colour levels 'correlate significantly' with winegrape price, they only explain about $60 \%$ of the variation in price. Other factors, of course, also affect winegrape price. The regional repu-

Table 3. Relationship of the price data $\left(\$ A t^{-1}\right)$ (regionally averaged), and regionally averaged biophysical quality estimators (colour and glycosylglucose concentrations) for the winegrape varieties Cabernet Sauvignon and Shiraz. The selected climate variables were derived from the data in Table 2. ${ }^{* *} \mathrm{p}<0.01 ;{ }^{*} \mathrm{p}<0.05$

\begin{tabular}{|c|c|c|c|c|c|c|}
\hline & $\begin{array}{l}\text { Winegrape } \\
\text { variety }\end{array}$ & $\begin{array}{c}\text { Winegrape } \\
\text { price } \\
\left(\$ A t^{-1}\right)\end{array}$ & $\begin{array}{l}\text { Colour } \\
\left(\mathrm{mg} \mathrm{g}^{-1}\right)\end{array}$ & $\begin{array}{c}\text { Glycosyl- } \\
\text { glucose } \\
\left(\mathrm{mg} \mathrm{g}^{-1}\right)\end{array}$ & $\begin{array}{r}\text { MJT } \\
\left({ }^{\circ} \mathrm{C}\right)\end{array}$ & $\begin{array}{c}\text { Diurnal } \\
\text { range } \\
\left({ }^{\circ} \mathrm{C}\right)\end{array}$ \\
\hline $\begin{array}{l}\text { Winegrape price } \\
\left(\$ \mathrm{~S} \mathrm{t}^{-1}\right)\end{array}$ & $\begin{array}{l}\text { Cab. Sauv. } \\
\text { Shiraz }\end{array}$ & $\begin{array}{l}1 \\
1\end{array}$ & & & & \\
\hline Colour $\left(\mathrm{mg} \mathrm{g}^{-1}\right)$ & $\begin{array}{l}\text { Cab. Sauv. } \\
\text { Shiraz }\end{array}$ & $\begin{array}{l}0.65^{* *} \\
0.63^{* *}\end{array}$ & $\begin{array}{l}1 \\
1\end{array}$ & & & \\
\hline $\begin{array}{l}\text { Glycosyl-glucose } \\
\left(\mathrm{mg} \mathrm{g}^{-1}\right)\end{array}$ & $\begin{array}{l}\text { Cab. Sauv. } \\
\text { Shiraz }\end{array}$ & $\begin{array}{l}0.67^{*} \\
0.47\end{array}$ & $\begin{array}{l}0.86^{* *} \\
0.71^{* *}\end{array}$ & $\begin{array}{l}1 \\
1\end{array}$ & & \\
\hline $\operatorname{MJT}\left({ }^{\circ} \mathrm{C}\right)$ & $\begin{array}{l}\text { Cab. Sauv. } \\
\text { Shiraz }\end{array}$ & $\begin{array}{l}-0.81^{* *} \\
-0.75^{* *}\end{array}$ & $\begin{array}{l}-0.79^{* *} \\
-0.81^{* *}\end{array}$ & $\begin{array}{l}-0.79^{* *} \\
-0.77^{* *}\end{array}$ & $\begin{array}{l}1 \\
1\end{array}$ & \\
\hline $\begin{array}{l}\text { Diurnal range } \\
\left({ }^{\circ} \mathrm{C}\right)\end{array}$ & $\begin{array}{l}\text { Cab. Sauv. } \\
\text { Shiraz }\end{array}$ & $\begin{array}{l}-0.17 \\
-0.18\end{array}$ & $\begin{array}{l}-0.15 \\
-0.21\end{array}$ & $\begin{array}{r}0.11 \\
-0.17\end{array}$ & $\begin{array}{l}0.37^{* *} \\
0.37^{* *}\end{array}$ & $\begin{array}{l}1 \\
1\end{array}$ \\
\hline $\begin{array}{l}\text { Summer rain } \\
(\mathrm{mm})\end{array}$ & $\begin{array}{l}\text { Cab. Sauv. } \\
\text { Shiraz }\end{array}$ & $\begin{array}{l}-0.30^{*} \\
-0.32^{*}\end{array}$ & $\begin{array}{l}-0.15 \\
-0.27\end{array}$ & $\begin{array}{r}0.20 \\
-0.14\end{array}$ & $\begin{array}{l}-0.09 \\
-0.09\end{array}$ & $\begin{array}{l}-0.25^{* *} \\
-0.25^{* *}\end{array}$ \\
\hline
\end{tabular}

MJT $\left({ }^{\circ} \mathrm{C}\right)$ and all of the quality variables, and for both varieties $(p<0.01)$ (Table 3$)$. These results are supported by some earlier studies in which Kliewer \& Torres (1972) associated ripening day temperatures of $35^{\circ} \mathrm{C}$ to reduced fruit colouration, whereas cool day temperatures of $15^{\circ} \mathrm{C}$ during ripening were beneficial to colouration. Kliewer (1977) in a later study showed that a prolonged day/night period of $37 / 32^{\circ} \mathrm{C}$ under high light apparently permanently blocked or inactivated the enzyme systems from forming anthocyanin and sugars in berries.

Both diurnal range and summer rain show few strong links with the quality indices (Table 3). The only significant relationship shown is that grape price is lower from regions with higher summer rain averages.

While several climate parameters that were identified in the first component of the PCA analysis (Table 2) could also have been suitable to use for further exploration of the climate-quality relationship, MJT $\left({ }^{\circ} \mathrm{C}\right)$ was selected because it exhibited a good correlation with quality parameters and the highest correlation with the price variable (Table 4). This climate index is also well recognised in Australian viticulture as a regionally representative climate indicator (Smart \& Dry 1980). In other wine regions of the world and in Australia, $\mathrm{GDD}_{10}\left({ }^{\circ} \mathrm{C}\right)$ is another commonly used climate index. A comparison of the relationship between average regional MJT $\left({ }^{\circ} \mathrm{C}\right)$ and $\mathrm{GDD}_{10}\left({ }^{\circ} \mathrm{C}\right)$ shows the strong correlation between these viticultural climate indices (Fig. 2).

Price $\left(\$ A t^{-1}\right)$ was selected from the quality indicators for use in developing 
Table 4. Relationship between winegrape price $\left(\$ \mathrm{~A} \mathrm{t}^{-1}\right)$ and selected climate drivers. ${ }^{* *} \mathrm{p}<0.01$

\begin{tabular}{|lc|}
\hline Pearson correlation & Grape price $\left(\$ \mathrm{~S} \mathrm{t}^{-1}\right)$ \\
\hline Grape price $\left(\$ \mathrm{~A} \mathrm{t}^{-1}\right)$ & 1 \\
Mean January temperature $(\mathrm{MJT})\left({ }^{\circ} \mathrm{C}\right)$ & $-0.64^{* *}$ \\
Growing degree days $\left.>10^{\circ} \mathrm{C}(\mathrm{GDD})_{10}\right)\left({ }^{\circ} \mathrm{C}\right)$ & $-0.57^{* *}$ \\
Latitude temperature index $(\mathrm{LTI})$ & $-0.58^{* *}$ \\
Harvest temperature $\left({ }^{\circ} \mathrm{C}\right)$ & $-0.60^{* *}$ \\
Annual rainfall $(\mathrm{mm})$ & $0.37^{* *}$ \\
Summer $(\mathrm{DJF})$ rainfall $(\mathrm{mm})$ & 0.04 \\
Potential evaporation summer $(\mathrm{DJF})(\mathrm{mm})$ & $-0.55^{* *}$ \\
Continentality $\left({ }^{\circ} \mathrm{C}\right)$ & $-0.39^{* *}$ \\
Diurnal range $\left({ }^{\circ} \mathrm{C}\right)$ & $-0.32^{* *}$ \\
Min. January temperature $\left({ }^{\circ} \mathrm{C}\right)$ & $-0.46^{* *}$ \\
\hline
\end{tabular}

the climate-response relationships. The price data were sourced from a greater number of wine regions, and, consequently, a larger range of climate types would be represented when exploring quality/climate responses. Across the 14 varieties tested, variation in MJT $\left({ }^{\circ} \mathrm{C}\right)$ explains $64 \%$ of the variation in winegrape price (Table 4).

\subsection{Further exploration of the climate-quality relationship}

Determination of the type of relationship between winegrape price and $\mathrm{MJT}\left({ }^{\circ} \mathrm{C}\right)$ was explored for each winegrape variety. Although the preceding analysis has been undertaken by testing linear relationships,

Temperature averages for winegrowing regions

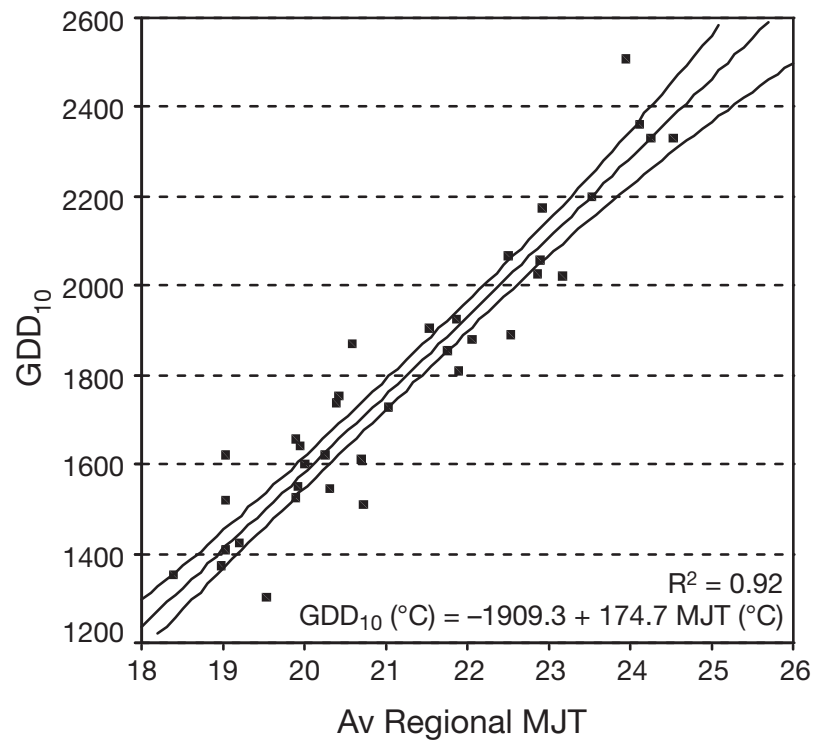

Fig. 2. Comparison of 2 well-used climate indices (MJT and growing degree days $>10^{\circ} \mathrm{C}\left[\mathrm{GDD}_{10}\right]$, both in ${ }^{\circ} \mathrm{C}$ ) calculated for the winegrowing regions of Australia ( $90 \%$ CIs are shown) more complex relationship profiles were explored here. By testing the significance of the second-order effect $(\mathrm{MJT})^{2}\left({ }^{\circ} \mathrm{C}\right)$ it was found that 4 of the premium winegrape varieties evaluated, Cabernet Sauvignon, Shiraz, Verdelho and Ruby Cabernet, displayed a significantly non-linear relationship to climate. The remainder displayed a linear relationship (data not shown).

Fig. 3 depicts the relationship between winegrape quality, indicated by winegrape price, and MJT $\left({ }^{\circ} \mathrm{C}\right)$ for selected premium red and white winegrape varieties. The more parabolic relationship describing the temperature-quality relationship in some cases (top 4 graphs depicted in Fig. 3) will be due to these varieties producing undesirable or poorer quality winegrapes in some of the cooler winegrowing regions relative to the quality that can be produced in the warmer regions. This could be explained by higher concentrations of methoxypyrazines or other compounds producing unripe flavours being produced when ripening temperatures are too cool (Coombe \& Iland 2004). These compounds can negatively affect quality, potentially suppressing prices paid for the winegrapes. An optimum price is achieved when the climate is most suited to the development of the best balance of flavour compounds. This is indicated by the turning point of the curve (top 4 graphs depicted in Fig. 3). As the climate warms past this optimum point, price declines. This decline could be explained by higher temperatures leading to excessive berry exposure and resultant reduced anthocyanin levels (Haselgrove et al. 2000). Jones et al. (2005) have also found that a quadratic relationship existed between vintage quality ratings and regional climate data globally.

Pinot Noir is one of the winegrape varieties where a linear relationship between winegrape quality and climate is displayed (lower 4 graphs depicted in Fig. 3). High prices can be paid for Pinot Noir produced in cool climates. This is one of the most important varieties used in sparkling wine production, and Pinot Noir table wine, from winegrapes grown in cool climates, can also command premium prices (Johnson 1989). Pinot Noir grapes are not suitable to be grown in hot climates as they ripen too early in the season. Of the white winegrape varieties, the quality of Semillon and Chardonnay are less sensitive to the temperature. Chardonnay commands high prices in cool climates, and this variety is also able to produce acceptable wine styles when grown in hotter climates. Semillon grapes grown in hot regions in Australia are used to produce a botrytised (i.e. infected by the 'noble rot' fungus Botrytis cinerea) dessert wine, ensuring high demand for this grape from the warmer climate. Cabernet Franc demonstrates the greatest sensitivity to temperature. This variety is typically used for blending with other 


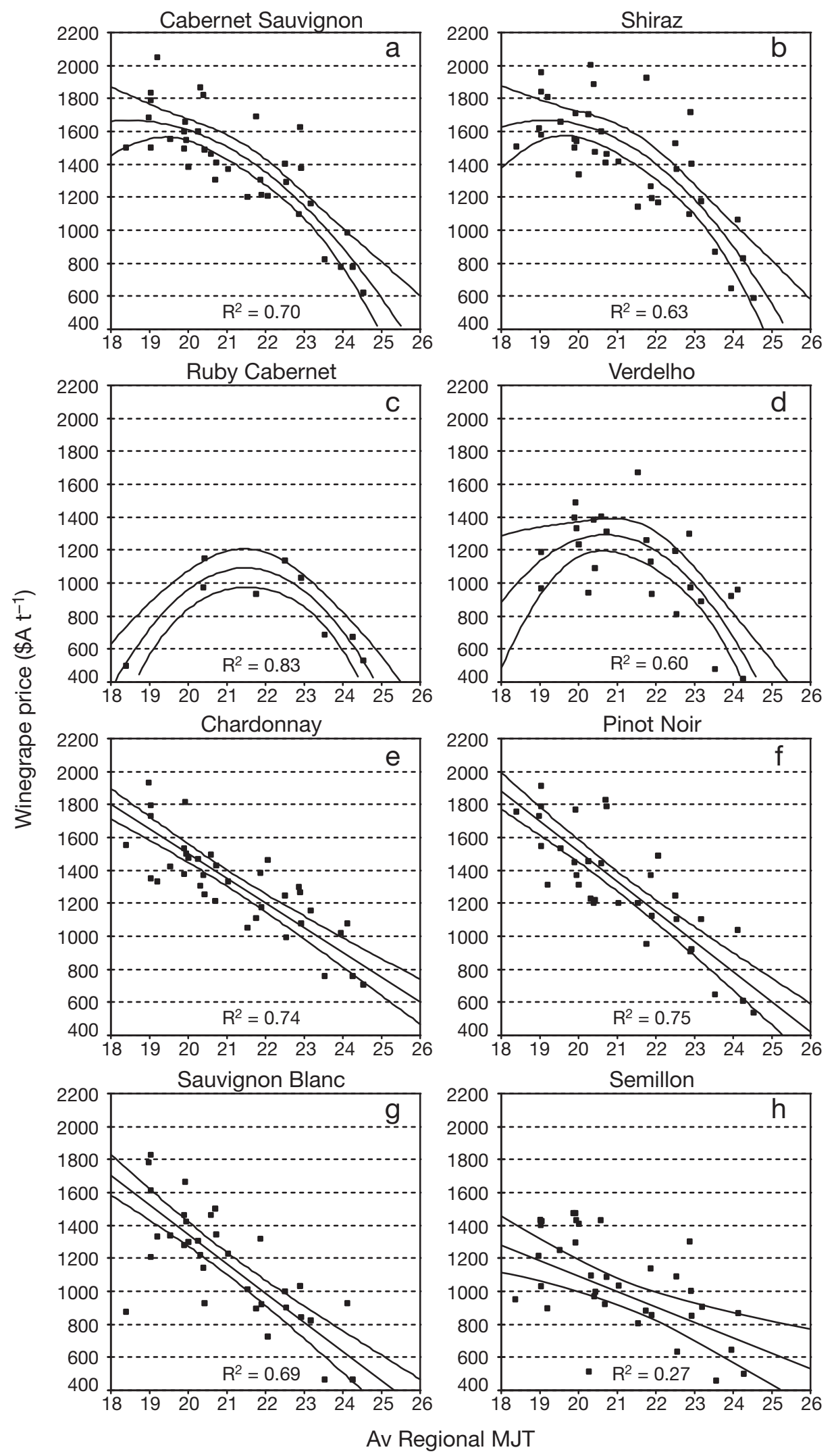

Fig. 3. Relationship between winegrape price $\left(\$ \mathrm{~A} \mathrm{t} \mathrm{t}^{-1}\right)$ and regional average $\mathrm{MJT}\left({ }^{\circ} \mathrm{C}\right)$ for selected varieties. Middle line: best fit regression relationship (see Table 5 ). The $90 \%$ CIs are shown for all varieties 
red winegrape varieties (Johnson 1989) so an explanation of this high sensitivity cannot be provided with regard to its product.

Regression analysis is used to create the model of winegrape price, as it relates to $\mathrm{MJT}\left({ }^{\circ} \mathrm{C}\right)$ and shows the variation in response for the different premium winegrape varieties (Table 5). The relationship is significant $(\mathrm{p}<0.05)$ for Grenache, and highly significant $(p<0.01)$ for all of the other varieties except Chenin Blanc and Colombard (not shown in Table 5). It is noted that the number of regions from which the pricing data was available, or where the variety was grown, varies for each variety.

Varieties displaying a parabolic price-climate relationship are represented first, and optimum temperatures for winegrape production are given. The optimum MJT $\left({ }^{\circ} \mathrm{C}\right)$ for the growing of Cabernet Sauvignon in Australia is $18.5^{\circ} \mathrm{C}$ (ranging between 17.1 and $19.2^{\circ} \mathrm{C}$, if the $90 \%$ CIs are calculated); for Shiraz, $19.1^{\circ} \mathrm{C}\left(18.2\right.$ and $\left.19.6^{\circ} \mathrm{C}\right)$; Verdelho, $20.7^{\circ} \mathrm{C}$ (20.4 and $\left.20.9^{\circ} \mathrm{C}\right)$; and Ruby Cabernet, $21.5^{\circ} \mathrm{C}\left(21.4\right.$ and $\left.21.6^{\circ} \mathrm{C}\right)$ (Table 5). In some cases, the longer season varieties are planted in cooler sites alongside the better suited varieties to decrease climate and financial risk by utilising a varietal mix. These plantings do reduce risk, but result in sub-optimum prices paid for these grapes, as the quality of the resulting wine can be less than optimum.

As previously mentioned, for some varieties the response is more linear. The slope of the line (value of $b 1)$ indicates the sensitivity of the variety to changes in temperature. The order of sensitivity has been presented (Table 5) to show that Cabernet Franc, Pinot Noir and Sauvignon Blanc are the most sensitive varieties, and Grenache, Semillon and Chardonnay are the least sensitive. It is known that in very cool climates winegrapes do not ripen (Prescott 1965). If these varieties were actually grown in Australia in sites too cool for them to ripen satisfactorily, a parabolic response might also be found.

Lower confidence is demonstrated for the cooler climate (e.g. $<19^{\circ} \mathrm{C}$ ) and warmer climate results (e.g. $>24^{\circ} \mathrm{C}$ ) than that of the mid-climate range, as indicated by the broader $90 \%$ CIs (Fig. 3). This would be an indication of the lesser representation of results from these climate types. In implementing the temperature sensitivity model in subsequent studies, definition of these CIs will allow uncertainties with regard to the quality-temperature sensitivity response to be calculated. Equations defining the upper and lower CIs of the models for each variety are presented in Table 5 .

To estimate errors for the quadratic models 1 extra step was necessary. The second-order effect, defined by the $(\mathrm{MJT})^{2}\left({ }^{\circ} \mathrm{C}\right)$ value, had to be converted to an independent variable and an orthogonal polynomial had to be created (Box et al. 1961). The model could then be treated like a multiple linear regression, and only then could the equation describing the upper and lower CIs be described.

Table 5. Quality-temperature model representing price $\left(\$ A t^{-1}\right)$ versus MJT $\left({ }^{\circ} \mathrm{C}\right)$ for premium winegrape varieties in Australia $(b 0$ : constant, $b 1$ : linear component and $b 2$ : quadratic component of the regression equation). Equations for $90 \%$ upper and lower CIs are also given. OT: optimum temperature $\left({ }^{\circ} \mathrm{C}\right)$, TSR: temperature sensitivity ranking. Model $b 2$ (curvature) significant at ${ }^{* *} \mathrm{p}<0.01 ;{ }^{*} \mathrm{p}<0.05$

\begin{tabular}{|c|c|c|c|c|c|c|c|c|c|c|c|c|c|c|}
\hline $\begin{array}{l}\text { Winegrape } \\
\text { variety }\end{array}$ & $\mathrm{R}^{2}$ & $\mathrm{df}$ & $\mathrm{p}$ & $b 0$ & $\begin{array}{l}\text { Model- } \\
\quad b 1\end{array}$ & $b 2$ & $b 0$ & $\begin{array}{c}\text { Upper C } \\
b 1\end{array}$ & $b 2$ & $\frac{}{b 0} \mathrm{~L}$ & $\begin{array}{c}\text { ower CI } \\
b 1\end{array}$ & $b 2$ & OT & TSR \\
\hline \multicolumn{15}{|c|}{ Quadratic (parabolic) relationship } \\
\hline $\begin{array}{l}\text { Cabernet } \\
\text { Sauvignon }\end{array}$ & 0.70 & 33 & $<0.001$ & -6988.2 & 936.8 & -25.4 & -3101.2 & 577.3 & -16.9 & -10875.0 & 1296.4 & -33.8 & $18.5^{*}$ & \\
\hline Verdelho & 0.60 & 22 & $<0.001$ & -22993.0 & 2348.1 & -56.8 & -17033.0 & 1806.4 & -44.3 & -28953.0 & 2889.7 & -69.2 & $20.7^{* *}$ & \\
\hline $\begin{array}{l}\text { Ruby } \\
\text { Cabernet }\end{array}$ & 0.83 & 6 & 0.005 & -26824.0 & 2599.9 & -60.5 & -22361.0 & 2204.1 & -51.6 & -31288.0 & 2995.7 & -69.5 & $21.5^{* *}$ & \\
\hline Shiraz & 0.63 & 33 & $<0.001$ & -10216.0 & 1241.8 & -32.4 & -5590.7 & 814.0 & -22.4 & -14841.0 & 1669.7 & -42.5 & $19.1^{*}$ & \\
\hline \multicolumn{15}{|c|}{ Linear relationship } \\
\hline Grenache & 0.31 & 18 & 0.012 & 4337.6 & -147.8 & - & 10217.6 & -666.9 & 11.8 & -1542.4 & 371.4 & -11.8 & & 9 \\
\hline Malbec & 0.41 & 17 & 0.003 & 4795.4 & -164.6 & - & 10260.0 & -659.7 & 11.5 & -669.2 & 330.4 & -11.5 & & 4 \\
\hline Merlot & 0.72 & 33 & $<0.001$ & 4819.4 & -160.7 & - & 6773.5 & -341.2 & 4.3 & 2865.4 & 19.7 & -4.3 & & 5 \\
\hline Pinot Noir & 0.75 & 32 & $<0.001$ & 5164.7 & -182.4 & - & 7222.0 & -373.8 & 4.6 & 3107.4 & 8.9 & -4.6 & & 2 \\
\hline Chardonnay & 0.74 & 35 & $<0.001$ & 4508.9 & -150.3 & - & 6164.8 & -303.4 & 3.7 & 2853.0 & 2.9 & -3.7 & & 8 \\
\hline Riesling & 0.58 & 31 & $<0.001$ & 4341.1 & -158.8 & - & 7075.9 & -416.3 & 6.2 & 1606.3 & 98.6 & -6.2 & & 7 \\
\hline $\begin{array}{l}\text { Sauvignon } \\
\text { Blanc }\end{array}$ & 0.69 & 33 & $<0.001$ & 4924.8 & -178.9 & - & 7232.8 & -394.0 & 5.2 & 2616.8 & 36.3 & -5.2 & & 3 \\
\hline Semillon & 0.27 & 33 & 0.002 & 2982.1 & -94.5 & - & 6062.7 & -378.5 & 6.7 & -98.5 & 189.6 & -6.7 & & 10 \\
\hline $\begin{array}{l}\text { Cabernet } \\
\text { Franc }\end{array}$ & 0.64 & 24 & $<0.001$ & 5138.0 & -182.9 & - & 8343.9 & -477.2 & 7.0 & 1932.2 & 111.3 & -7.0 & & 1 \\
\hline Traminer & 0.58 & 15 & $<0.001$ & 4381.7 & -160.7 & - & 8423.8 & -530.0 & 8.7 & 339.7 & 208.6 & -8.7 & & 6 \\
\hline
\end{tabular}




\section{CONCLUSIONS}

Quantitative assessments of impacts of a changing climate on winegrape quality have not been determined previously. A study of inter-regional differences in climate and the comparative variation in quality was chosen as a method of estimating climate effects on winegrape quality. Data from regions used in this analysis span across a wide range of climates, from 'cool climate' through to 'hot climate' regions in Australia.

Winegrape quality-temperature response models were produced for the premium winegrape varieties grown in Australia. Variations in sensitivity to temperature of these varieties were highlighted, and, in some cases, optimum temperatures for production of particular varieties were defined. We have established regression relationships that will enable modelling of the impact of climate change on the Australian wine industry to be achieved and future risk assessment and planning to begin.

Though this assessment was carried out using Australian winegrape quality data and Australian regional climates, we would expect the general nature of the temperature and wine quality to be similar in other winegrowing regions of the world. The sensitivity of winegrapes and wine to temperature has been explored in other countries with the same overall conclusions (Jones et al. 2005); however, the structure between each region's climate and varietal quality may differ from the results found in this work as regional wine styles and quality expectations vary around the world.

Acknowledgements. We thank the Australian Wine Research Institute, in particular, M. Gishen for his advice, support and provision of the wine quality data set, the Australian Wine and Brandy Corporation and E. Sullivan for providing the wine regions map, and Dr I. Smith and K. Hennessy (CSIRO) for their critical review of this document. Thanks also to S. Bentley (CSIRO) for advice regarding statistical interpretation.

\section{LITERATURE CITED}

Allen W (2003) Winegrape assessment in the vineyard and at the winery. Australian Viticulture 7:20-41

Amerine MA, Winkler AJ (1944) Composition and quality of musts and wines of California grapes. Hilgardia 15: 493-674

AWBC (Australian Wine and Brandy Corporation) (2003) Annual report. Wine Australia, Industry House, National Wine Centre, Adelaide. Available at www.wineaustralia.com/ Australia/Default.aspx?tabid=148 (Accessed 13 November 2007)

AWBC (Australian Wine and Brandy Corporation) (2006) Australian Wine and Brandy Corporation website. Available at www.wineaustralia.com/Australia/Default.aspx?tabid= 302 (Accessed 13 November 2007)

BoM (Bureau of Meteorology) (2007) Bureau of Meteoro- logy website. Available at www.bom.gov.au/index.shtml (Accessed 13 November 2007)

Box GE, Cousins WR, Davies OL, Himsworth FR and others (1961) Statistical methods in research and production, with special reference to the chemical industry, 3rd edn. Oliver and Boyd, London

Cichelli A, Damiani F, Murmura F, Simonetti MS, Odoardi M, Damiani P (2000) Classification of Montepulciano d'Abruzzo wines by linear discriminant analysis and artificial neural networks. Am J Enol Vitic 51:108-114

Coombe BG (1987) Influence of temperature on composition and quality of grapes. Acta Hortic 206:23-35

Coombe BG, Iland P (2004) Grape berry development and winegrape quality. In: Dry PR, Coombe BG (eds) Viticulture, Vol 1. Resources, 2nd edn. Winetitles, Adelaide, p 210-248

Edwards F, Spawton T (1990) Pricing in the Australian wine industry. Eur J Mark 24:11-17

ESRI (Environmental Systems Research Institute) (2007) ArcINFO GIS mapping software. Available at www.esri.com/ software/arcgis/arcinfo/about/features.html (Accessed 13 November 2007)

Francis L, Armstrong H, Cynkar W, Kwiatkowski M, Iland P, Williams P (1998) A national vineyard fruit composition survey - evaluating the G-G assay. Aust NZ Grapegrower Winemaker 414a:51-58

Francis L, Iland P, Cynkar W, Kwiatkowski M and others (1999) Assessing wine quality with the G-G assay. In: Blair RJ, Sas AN, Hayes PF, Hoj PB (eds) Proc 10th Aust Wine Industry Techn Conf, Sydney. Winetitles, Adelaide, p 104-108

Gladstones J (1992) Viticulture and environment. Winetitles, Adelaide

Golan A, Shalit H (1993) Wine quality differentials in hedonic grape pricing. J Agric Econ 44:311-321

Günter S, Anderson K (2003) Wine quality and varietal, regional and winery reputations: hedonic prices for Australia and New Zealand. Econ Rec 79(246):357-369 doi: 10.1111/1475-4932.00109

Haeger JW, Storchmann K (2006) Prices of American Pinot Noir wines: climate, craftsmanship, critics. Agric Econ 35: $67-78$

Haselgrove L, Botting D, Van Heeswijck R, Hoj PB, Dry PR, Ford C, Iland PG (2000) Canopy microclimate and berry composition: the effect of bunch exposure on the phenolic composition of Vitis vinifera L. CV. Shiraz grape berries. Aust J Grape Wine Res 6:141-149

Hooke H, Kyte-Powell R (2003) The Penguin good Australian wine guide 2003/2004. Penguin books, Camberwell

IPCC (Intergovernmental Panel on Climate Change) (2007) Climate change 2007: the physical science basis, summary for policymakers. Cambridge University Press, Cambridge

Jackson DI, Cherry NJ (1988) Prediction of a district's graperipening capacity using a latitude temperature index (LTI). Am J Enol Vitic 39:19-28

Jackson DI, Lombard PB (1993) Environmental and management practices affecting grape composition and wine quality-a review. Am J Enol Vitic 44:409-430

Johnson H (1989) The world atlas of wine. Mitchell Beazley, London

Jones GV, White MA, Cooper OR, Storchmann KH (2005) Climate change and global wine quality. Clim Change 73 : 319-343

Kerridge GH, Antcliff AJ (1996) Winegrape varieties of Australia. CSIRO Publishing, Collingwood

Kliewer WM (1977) Influence of temperature, solar radiation and nitrogen on colouration and composition of emperor 
grapes. Am J Enol Vitic 28:96-103

Kliewer WM, Torres RE (1972) Effect of controlled day and night temperatures on grape colouration. Am J Enol Vitic 23:71-77

Koundouras S, Marinos V, Gkoulioti A, Kotseridis Y, van Leeuwen C (2006) Influence of vineyard location and vine water status on fruit maturation of nonirrigated cv. Agiorgitiko (Vitis vinifera L.). Effects on wine phenolic and aroma components. J Agric Food Chem 54:5077-5086

Magarey PA, Wachtel MF, Emmett RW (1994) Disease management - overview. In: Nicholas P, Magarey P, Wachtel $M$ (eds) Diseases and pests. Grape Production Series, No. 1. Winetitles, Adelaide, p 75-80

Marais J, Calitz F, Haasbroek PD (2001) Relationship between microclimatic data, aroma component concentrations and wine quality parameters in the prediction of Sauvignon Blanc wine quality. S Afr J Enol Vitic 22:47-51

Nakićenović N, Swart R (eds) (2000) Special report on emissions scenarios: a special report of Working Group III of the Intergovernmental Panel on Climate Change. Cambridge University Press, Cambridge

Nemani RR, White MA, Cayan DR, Jones GV, Running SW, Coughlan JC, Peterson DL (2001) Asymmetric warming over coastal California and its impact on the premium wine industry. Clim Res 19:25-34

Oczkowski E (1994) A hedonic price function for Australian premium table wine. Aust J Agric Econ 36:628-647

Oczkowski E (2006) Modeling winegrape prices in disequilibrium. Agric Econ 34:97-107

Osmond R, Anderson K (1998) Trends and cycles in the Australian Wine Industry, 1850-2000. Centre for International Economic Studies, Adelaide

Page CM, Jones RN (2001) OzClim: the development of a climate scenario generator for Australia. In: Ghassemi F, Whetton P, Little R, Littleboy M (eds) Integrating models

Editorial responsibility: Nils Chr. Stenseth, Oslo, Norway for natural resources management across disciplines, issues and scales, Part 2. MODSIM 2001, Int Congr on Modelling and Simulation. Modelling and Simulation Society of Australia and New Zealand, Canberra, p 667-672

Prescott JA (1965) The climatology of the vine (Vitis vinifera, L.). The cool limits of cultivation. Transactions of the Royal Society of South Australia 89:5-23

> Rodo X, Comin FA (2000) Links between large-scale anomalies, rainfall and wine quality in the Iberian Peninsula during the last three decades. Glob Change Biol 6: $267-273$

$>$ Seguin G (1986) 'Terroirs' and pedology of wine growing. Cell Mol Life Sci 42:861-873

Smart RE, Dry PR (1980) A climatic classification for Australian viticultural regions. Aust Grapegrower Winemaker, April 8 and 10, Winetitles, Adelaide

Spayd SE, Tarara JM, Mee DL, Ferguson JC (2002) Separation of sunlight and temperature effects on the composition of Vitis vinifera cv. Merlot berries. Am J Enol Vitic 53: $171-182$

SPSS (2001) SPSS Brief guide. SPSS Inc., Chicago, IL

- Tonietto J, Carbonneau A (2004) A multicriteria climatic classification system for grape-growing regions worldwide. Agric For Meteorol 124:81-97

Unwin T (1999) Hedonic price indexes and the qualities of wines. J Wine Res 10:95-104

WFA (Winemakers Federation of Australia) (2007) Wine Australia: directions to 2025-An industry strategy for sustainable success. WFA, Adelaide. Available at www. wfa.org.au/strategy2025.htm (Accessed 22 January 2008)

- White MA, Diffenbaugh NS, Jones GV, Pal JS, Giorgi F (2006) Extreme heat reduces and shifts United States premium wine production in the 21st century. Proc Natl Acad Sci USA 103:11217-11222

Submitted: July 30, 2007; Accepted: February 7, 2008 Proofs received from author(s): April 11, 2008 